\title{
Smart Cities Landscape and Urban Planning for Sustainability in Brno City
}

\author{
Jitka Fialová $^{1} \mathbb{D}$, Dastan Bamwesigye ${ }^{2, * \mathbb{D}}$, Jan Lukaszkiewicz $^{3} \mathbb{D}$ and Beata Fortuna-Antoszkiewicz ${ }^{3} \mathbb{D}$ \\ 1 Department of Landscape Management, Faculty of Forestry and Wood Technology, \\ Mendel University in Brno, Zemedelska 3, 61300 Brno, Czech Republic; jitka.fialova@mendelu.cz \\ 2 Department of Forest and Wood Products Economics and Policy, Faculty of Forestry and Wood Technology, \\ Mendel University in Brno, Zemedelska 3, 61300 Brno, Czech Republic \\ 3 Department of Landscape Architecture, Institute of Environmental Engineering, \\ Warsaw University of Life Sciences-SGGW, ul. Nowoursynowska 159, 02-776 Warszaw, Poland; \\ jan_lukaszkiewicz@sggw.edu.pl (J.Ł.); beata_fortuna_antoszkiewicz@sggw.edu.pl (B.F.-A.) \\ * Correspondence: dastan.bamwesigye@mendelu.cz
}

Citation: Fialová, J.; Bamwesigye, D.; Łukaszkiewicz, J.;

Fortuna-Antoszkiewicz, B. Smart Cities Landscape and Urban Planning for Sustainability in Brno City. Land 2021, 10, 870. https://doi.org/ 10.3390/land10080870

Academic Editor: Richard C. Smardon

Received: 13 July 2021

Accepted: 17 August 2021

Published: 19 August 2021

Publisher's Note: MDPI stays neutral with regard to jurisdictional claims in published maps and institutional affiliations.

Copyright: (c) 2021 by the authors. Licensee MDPI, Basel, Switzerland. This article is an open access article distributed under the terms and conditions of the Creative Commons Attribution (CC BY) license (https:/ / creativecommons.org/licenses/by/ $4.0 /)$.

\begin{abstract}
This study aimed to explore the case study of Brno city regarding smart city models. We analyzed Brno considering smart and sustainable city elements, i.e., smart mobility/public transport, smart technology, smart people, smart governance, smart economy, smart living, and smart environment based on transport, energy, and environment referred herein as the smart city and sustainability model. Therefore, we investigated a case study of Brno city in the Czech Republic. We used qualitative techniques such as case study, exploration, observation, and description. We analyzed and comprehended the trends in the various features of smart city and sustainable development of the city of Brno. The findings showed that Brno city is doing its best to maintain smart city models through its governance organs and structures. The city is also working hard to improve some of the aspects that are still lagging. The ongoing developments and the future ones are based on strategic planning for both the short term and long term such as Brno2023, Brno2030, and Brno2050. It was found that Brno has a very well-planned transport system and is integrated with other aspects such as technology, energy, such as the electricity that moves the trolleybuses and trams, and environment. We strongly conclude that even though Brno city still struggles to achieve total sustainability, it is still a model and reflection of a smart and sustainable city. Finally, we noted that Brno city has very good plans and vision the "DNA" of a smart city. However, the implementation still suffers political willingness.
\end{abstract}

Keywords: urban landscape sustainability; Brno city; case study; smart economy; smart people; smart environment; smart infrastructure development

\section{Introduction}

In Europe and the United States of America (USA), at the turn of the 20th and 21st centuries, there was a clear change in the theory and practice of city planning. Since computerization was becoming more common in the 1980s and 1990s, it began to be a key influence in this area [1-3]. The idea of Smart city (S.C.) can be described as a turning point in the history of urban planning, precisely, the same way as in the past decades, e.g., the significant reconstruction of European cities in the post-war period, which dominated the second half of the 20th century in the continent. The implementation of this new urban paradigm - although not without difficulties - means that information technologies are used to an increasing extent to solve problems limiting the sustainable development of modern cities [4-7].

In common understanding, a Smart City (S.C.) is one in which Information and Communication Technology (ICT) is of crucial importance for managing all its most essential functions. The scale of the increase in the phenomenon is illustrated by the data from the 
last ten years. In 2012, 143 documented cases of cities implementing S.C. solutions were described worldwide [8]. On the other hand, less than two years later (before 2014) in the EU alone, 240 cities with more than 100,000 inhabitants could be identified (including Brno, as the example), which had real achievements in this area [9]. In February 2020, already during the COVID-19 pandemic, the influential research company International Data Corporation (IDC) predicted that over the next ten months, global spending on smart cities would amount to 124 billion US dollars. This represents an increase of $19 \%$ compared to the 2019 expenditure for this purpose, focusing on investment priorities on more advanced public transport, intelligent traffic management, urban lighting and public safety [4].

It can be seen that COVID-19 from 2020 and 2021 only accelerated the already dynamically growing global spending on smart cities. It can be assumed that as a result of the lockdown, the massive demand for ICT technologies will become a stimulus that will most likely in the coming years lead to the dependence of the functioning of cities in the world on the sophisticated Internet of Things (IoT) [10].

The concept of smart cities (S.C.) carries different meanings to people and varies from one city to another. The European Commission describes smart cities as "a place where traditional networks and services are made more efficient with the use of digital and telecommunication technologies to benefit its inhabitants and business" [11,12]. The commission also clarifies S.C. that they tap information and communication technologies to better use resources, reduce emissions, and implement sustainable development. However, this implies that cities develop more innovative models of transport networks, efficient lighting and heating in buildings, better disposal facilities, and an upgraded waste and water supply system [11-13]. The concept also involves interactions and responses to the city's administrative needs, safety in public places, and meeting specific population groups (the young and aged). Becoming a smart city is a vital goal of all modern cities. Many cities strive to reach smartness in various fields such as technology, the safety of citizens, the economy, and the environment in the most recent given the benefits [12-14].

Smart cities vary across countries; this is attributed to geopolitical context and pertinent issues. Regardless, smart cities are known to revolve around initiatives that use innovation to make urban service delivery more efficient and increase overall competitiveness and sustainability [13]. The definition provided by the OECD considers initiatives and approaches that foster effective leveraging of digital platforms and other innovations to improve citizen wellbeing and provide inclusive, sustainable, and efficient services to urban environments through collaboration with multiple stakeholders.

A smart city as a concept focuses on mitigating the adverse impact urban growth may encounter while attaining social, economic, and environmental sustainability [11-16]. Therefore, cities and countries shifting towards smart cities aim at improving urban life by integrating Information and Communications Technology (ICT) solutions and sustainable practices to address policy, energy, transport, and mobility challenges. We can conclusively say that smart and sustainable cities rotate on the elements that form the Smart City and Sustainability Model (SCS Model) based on previous studies [11,15-24]:

- smart mobility/public transport;

- smart technology;

- smart people;

- smart governance;

- smart economy;

- $\quad$ smart environment (waste management, public spaces, and greenery spaces/parks);

- smart living.

This study, therefore, investigated a case study of Brno city in the Czech Republic in the light of the smart city and sustainable development. The main question was, does Brno city meet the standards of smart city status? We hypothesized that Brno city covers aspects of smart city. 
Therefore, we explored and analyzed major concepts of S.C. in the city of Brno grounded on transport, energy, and environment referred to herein as the Smart City and Sustainability Model (SCS Model).

\section{Materials}

\subsection{Elements of Smart Cities}

At the core of smart cities are elements that encapsulate the necessary models on which governments are expected to base their urban development processes. A study by Gil-Garcia et al. classified smart city components to explain them categorically based on a framework, including public services, city administration, and management [15]. Other elements are: policies and other institutional arrangements, governance, engagement and collaboration, human capital and creativity, knowledge economy and pro-business environment, built environment and city infrastructure, natural environment and ecological sustainability, ICT, and other technologies, data, and information.

Cities become better when they adopt effective and efficient means of production and deliver critical services needed. Under public service, transportation, public safety, culture, tourism and recreation, health and social services, and emergency responses and management are crucial elements that should be delivered to people [16]. These domains reflect the challenges cities must address to improve conditions and the wellbeing of people. Hence, smart cities emerge when we develop, maintain, and upgrade their assets to foster tourism, recreation, and culture.

This domain identifies the need to set up a supportive administrative environment in a city. Cities must focus on organizational capacity, design strategies, and leadership to attain intelligence [16]. Gil-Garcia et al. report that local authorities must engage in appropriate technology and involve an efficient organizational framework to ensure funding, staffing, and performance [15]. Hence, this requires the leadership of city managers and mayors to engage in understanding and development.

Governments can develop cities when they create policy instruments that drive the future with a purposeful vision. The influence of institutional arrangement is significant in setting regulations, laws, and norms to be followed [16]. Findings indicate that to achieve better government settings, selecting, designing, adopting, using information technologies, and implementing factors should be emphasized [15]. Therefore, smart cities are based on developing policy aspects that foster innovation.

This component considers the regulatory and legal frameworks different actors take in developing smart cities. Under governance, e-governance, networks, partnerships, and collaboration, engage stakeholders, communities, and citizens. The concept entailed here focuses on establishing structures that integrate governments with social expectations [6].

Human capital and creativity, and knowledge economy and pro-business environment.

These elements focus on people, learning, knowledge, and education as critical factors in developing smart cities. Gil-Garcia et al. acknowledge that smart cities are based on individual brilliance through training, arts, culture, education, and the creative industry [5]. By building social infrastructures, cities empower human capital to support sustainable development and contribute knowledge.

This component concerns the high-tech industry, economic knowledge, businessfriendly environment, and the creative industry. Smart cities are expected to house media platforms, industries, and technology centers to drive growth through health business [15].

\subsection{Built Environment and City Infrastructure}

This element focuses on physical infrastructures: roads, buildings (recreational, business, and residential), roads, railways and tram lines, tunnels, bridges, electrical and communication lines, pipelines, and many others. These infrastructures are expected to ensure safety, protect residents, and foster accessibility to different living areas' dimensions [16].

Smart cities have a vision of becoming green and clean places. This concept addresses ecological challenges by adopting sustainable practices such as renewable energy, protect- 
ing natural habitats, reducing noise pollution, monitoring air quality, and scaling down fuel emissions. Rational protection of cities' existing natural resources and planned, constant development are of key importance here. Maintaining mature trees, introducing various forms of urban greenery, and increasing the biologically active area (especially in the center zone) are the basic conditions for achieving a clean and healthy city $[25,26]$.

\subsection{ICT and Other Technologies, and Data and Information}

The level of communication and technologies used in smart cities differentiates them from others. For instance, smart cities build virtual, wireless, and ubiquitous systems to connect and ease lifestyles' mobility. Technological development in smart cities involves interconnections between networks, virtual systems, and other architectures [17].

Smart cities are considered an upgrade due to the capacity to share and process information through ICT sources. The future of interconnections requires real-world data and real-time integration of stimulating developments to improve decision-making processes [17]. Hence, smart cities advance because they build information-based infrastructures to provide viable solutions.

\subsection{The Role of Governance in Achieving Smart Cities}

The conceptualization of smart cities is a process that accounts for governance, and decision making is a collective approach to ensure the promotion of city management by the government. Several researchers highlighted that implementing policies is a governance role that promotes structures to ensure that smart cities exist [18]. Other studies indicate that smart cities exist; urban governments must endorse higher education centers to achieve them [19]. Profoundly, this idea resonates with Gil, Carvalho, and Paiva, who claimed that the governance of the smart city must focus on initiatives aimed at achieving the fate [20]. In this concept, it is relevant that policy making is a significant priority for city governments. Dijon's city's impact on governance was illustrated when it introduced street lighting management, quality of WI-FI services, and smart traffic management by centralizing the solutions [13]. Hence, it is through governance that smart cities get to adopt policies tailored to meet global standards. Similar examples of cities are represented by Bristol or Warsaw [27,28].

Cities are a convergence of multiple cultures and territories, ideal for local authority contradictions due to distinct interactions and conflicts about decisions. When authorities disagree on sustainable development (social, environmental, and economic), cities cannot be efficiently managed [21]. However, with studies on Information and Communications Technology (ICT) and governance, interactions between local authorities have changed the trend to focus on solutions that merge government roles to foster growth. Bamwesigye and Hlavackova argued that combining ICT tools with the government helps in decision making, focusing on uniting people's ideas to achieve sustainability [22]. Furthermore, considering that smart cities target sustainability, cultural differences can change cities' outlook [18]. This sentiment requires administrative structures and government agencies to involve stakeholders in transforming the interactive system to ensure inclusion [20]. Therefore, smart cities' governance is related to leadership models that promote merging cultures to achieve interaction and collaboration.

According to the research, governments have taken an innovative approach to reduce costs, connect environments, and engage different problem-solving stakeholders [23]. Successful cities' innovations require governments to integrate ICT in strategic administration to reform government institutions [21]. Moreover, the digitalization government can transform organizations by improving public sectors' efficiency to provide services and deliver societal solutions [24]. This concept's operationalization relies on transparency and openness in building citizen-centric services to engage in sustainable activities [29]. In this sense, the government assumes oversight to increase communication ability and reduce human error in institutions. Therefore, governance is a crucial step towards implementing innovative approaches that focus on reducing operational pressures. 


\subsection{Government Intervention to Achieve Smart Cities}

In cities aspiring to attain smart status, increasing citizens' needs for democratic practices have emerged through government involvement. Governments have the investment capacity to advance ICT as a channel that focuses on improving communication and interactions with citizens [30]. Given that smart cities rely on attracting people to engage in innovations and advance sustainable growth-seeking, both the private and public sectors use interventions that foster development [31]. Social inclusion has become a priority in Spain after recording high numbers of older people dying in solitude, yet policies can be implemented to track people [32]. In developing smart cities, it is interesting that governments engage citizens on all fronts because social issues are different across regions [29]. Therefore, the degree of government involving citizens impacts the process of achieving governance in smart cities.

Improving public service efficiency in delivering essential activities has become a core purpose for smart cities. By financing smart cities' technological needs for development, the government must improve public service to reduce transaction costs when contracted efficiently [23]. This can enable efficient information, health, education, and transportation management to improve production and infer knowledge to generate essential services [33]. Other studies indicate that urban infrastructures are developed to provide essential services vital to health and sustainability [34]. In this regard, smart cities rely on governance that adopts practices to increase residents' welfare and sustainable development aims [35,36].

While discussions about governments' involvement in smart cities have been broadly covered, outlining development needs must emphasize problem-solving. Voordijk and Dorrestijnss claim that citizens should participate in local administration structuring through democracy [24]. Smart cities' results show that governments moving towards an allinclusive governance approach are on a higher development trajectory than their counterparts [20]. Other researchers found that introducing smart technology has influenced urban neighborhoods' sustainability as cities seek low densities and operational costs [22]. The arrangements being taken by governments to address problems show that integrating solutions with the public is essential for smart cities because they must serve citizens.

Government interventions to achieve smart city status have focused on including disadvantaged and vulnerable populations [37]. In both developed and developing countries, smart cities aim to promote the inclusion of disadvantaged people. According to Mutiara, Yuniarti and Pratama, smart cities' development targets go beyond the quality of life and uplifting of underprivileged persons because enhancing their capabilities can contribute to equality diversity [38]. By addressing issues hindering social justice, governments can adopt reforms to ensure the participation of various groups in meeting the development needs of smart cities [35]. When developing information technology, underprivileged populations must be accounted for to benefit from the developments. Smart cities should be the governments' way of achieving sustainable development goals by integrating societies' fundamental needs.

\subsection{Primary Tools in the Governance of Smart Cities}

Technology is a leading tool in smart cities' governance, and the physical foundations of all initiatives are developed around it. In cities such as London, Meijer and Bolívar established that the concept of "datafication", which was made possible with IoT (Internet of Things), to build infrastructures with the potential of advancing sustainability [39]. Other studies paint that governments use technology to easily equip everyday objects with digital communication controllers to communicate and interconnect regions through smart devices [40]. In Brazil, blockchain technology has led to transparency in medical records, privacy, and lowering costs by designing smart contracts [41]. Therefore, ensuring the proper use of technology is crucial to governing smart cities because it fosters connectivity.

The impact of human capital is indispensable in developing and governing smart cities. As several researchers suggest, governments must ensure that citizens attain sufficient technical and education skills to help them navigate the smart city environment [42]. 
Another study provided an example of the Romanian government, which created "knowledge cities" by launching e-government portals to engage stakeholders in the private and public sectors' vital services [43]. Human capital benefits in the governance of smart cities; initiatives must be taken to ensure efficient operations by enhancing adaptation to handling privacy and security issues within the city environment [44]. However, many cities aiming for a smart status still lack the technical capacity to integrate applications with people [45]. Hence, by training human capital, smart cities can develop more by sourcing the best management through technical capacity-building.

The active participation and engagement of citizens in the development of smart cities can lead to enhanced governance. Various scholars identified active engagement as a crucial facet of empowering citizens, fostering digital inclusion, collaboration, and changing perceptions among communities [33]. Paris commissioned vegetation as a bio-air conditioning source in France by turning rainwater into clean energy involving farmers [46]. Further, the same study established that the ranking of smart European cities such as Lisbon, Berlin, London, Helsinki, and Copenhagen shows that they pay attention to smart sustainability, improved bicycle networks, wastewater treatment, and unemployment [46]. This development level is attributed to citizen participation in symposiums exploring flexible ways of creating partnerships to address private and public sector concerns that limit improvements.

Other researchers suggested that urban planning is a purpose-driven approach using data to analyze populations' needs in smart cities [22,47]. For instance, the Smart London Plan was developed based on data technologies to improve citizens' welfare by identifying areas that require refining. Bamwesigye and Hlavackova suggest that smart cities adopt plans to promote approaches by utilizing information consistent with opportune areas where developers use necessary changes tailored to meet people's social needs without compromising the future needs [22]. This entails finding future physical objects that will impact lives and develop and merge them with current urbanism elements for sustainable development.

\subsection{Methods}

This study used qualitative approaches such as case study, exploration, and description pronounced by Creswell [48]. Qualitative research methods are used in descriptive anthropology, narrative research, exploration, and case studies. Therefore, we used exploratory techniques, case study of Brno city, photographs, literature, and content analysis [48-62]. Additionally, quantitative data were analyzed to comprehend the trends in the different aspects of smart city and sustainable development of Brno.

A case study of Brno was selected and explored concerning smart city options and models. We based our study on a smart city and sustainability model (SCSM) of environment, technology, and people's quality and livelihood. Strategic documents of Brno city were also analyzed to see if they conform to sustainability aspects of smart cities.

This study explores the city of Brno. We studied the history of this city in terms of socioeconomic and structural changes over the decades.

To fulfill the study's aim, an extensive study of the related literature on smart city options and sustainability. Major keywords included are smart city, urban green infrastructure/green spaces, bult areas, smart transport, smart environment, smart city governance, and sustainability. Some important databases such as Scopus, Web of Science and google scholar were searched for related study materials. Based on all the materials, we give an expert view of Brno city given smart city and sustainable development.

At the heart of Europe, Brno city connects major cities such as Vienna, Prague, and Bratislava. It is an important city in both local and international development, economically and structurally (Figure 1). 


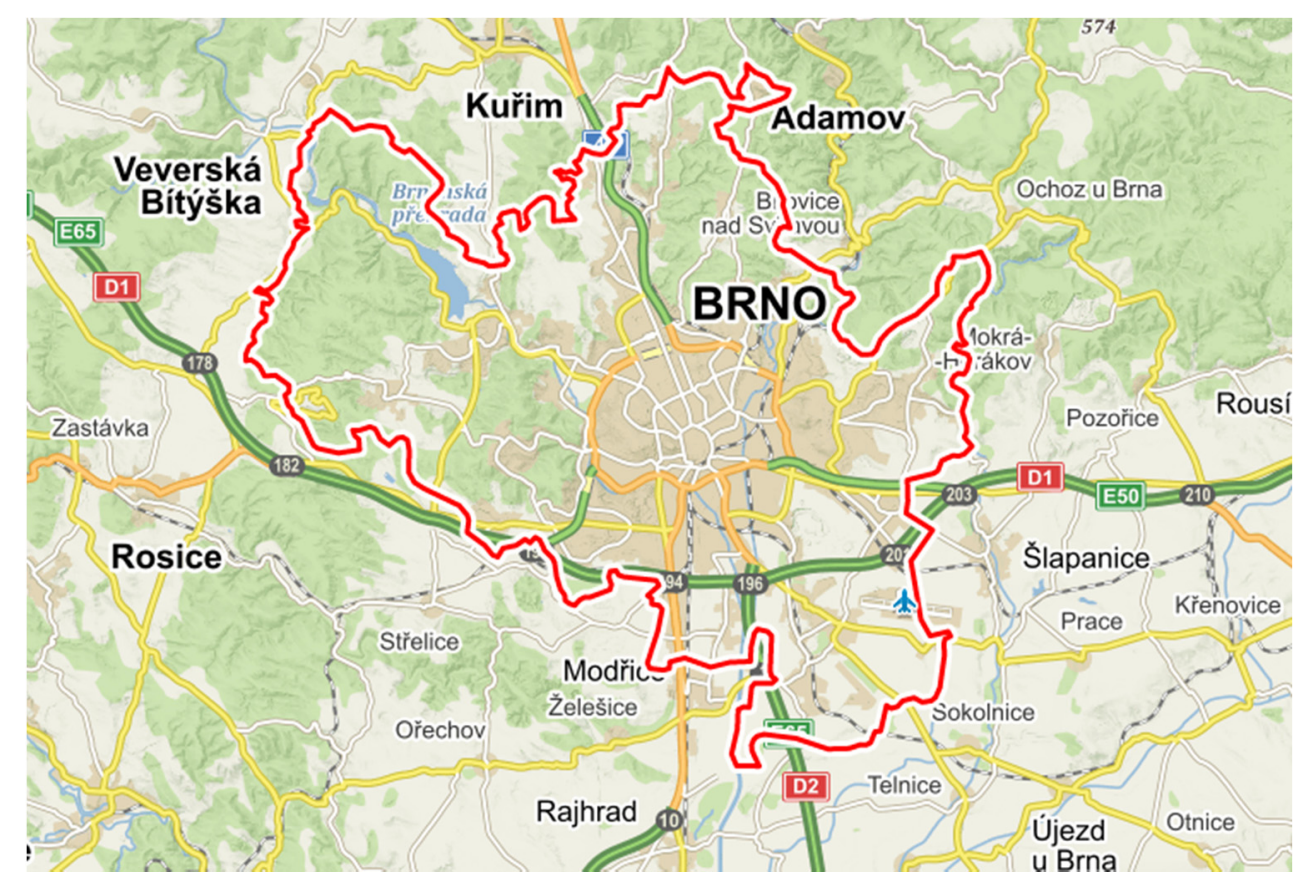

Figure 1. A map of Brno and the location of Brno city [63].

The city of Brno has approximately 400,000 inhabitants and about another 150,000 people travel to the city daily for work, education and or other services. There, the future of such a city needs a constant debate on best options of sustainability. The city of Brno is often perceived only as a political symbol or offices; similarly, it forms city districts, city companies or establishments. Brno participated in preparing the strategy with partners from universities, research centers, companies, non-profit organizations, and active individuals [44,51-53].

The Strategy Brno2050 is the basic strategic development document of the city of Brno. The subsequent strategy is the strategy of the city of Brno and its inhabitants. The main advantage is the setting of key goals and priorities for the city's sustainable development. The strategy creates an agenda for the direction of some sectoral policies and the basis for active action decision making in the medium and long term of the city development journey (Figure 2) [44,51,52].

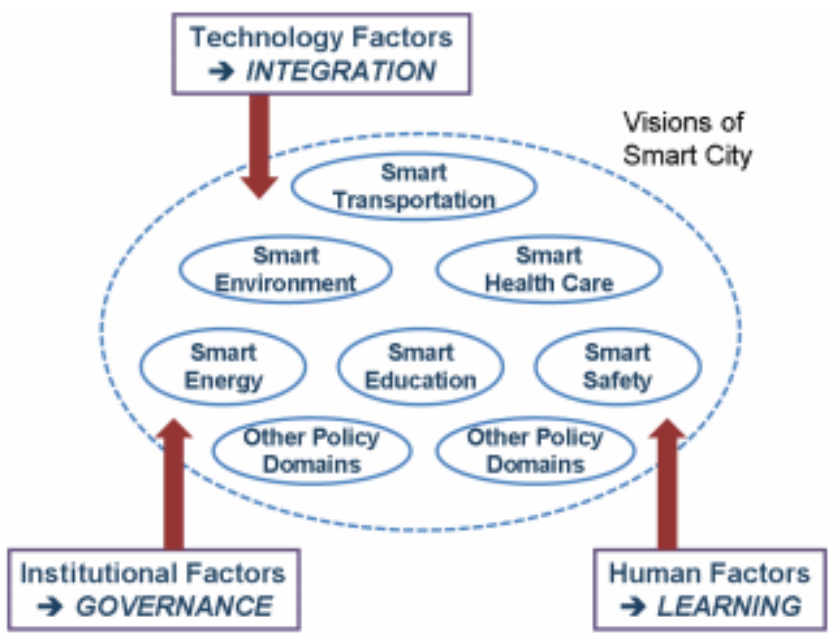

Figure 2. Strategic directions for a sustainable smart city (prepared by authors) [22,48,52,58-79].

The history of S.C. options in Brno can be traced as far as 1884 to 1899. In 1884, the joint-stock company "Brünner Damf-Tramway" (Brno Steam Tram) was founded, which, on 24 May 1884, started operations of a steam street railway on the Pisárky-Královo Pole 
line. Another line extended the line in the Václavská-Central cemetery, 15 locomotives and 31 trailers were put into operation in sequence. In 1886, a new company was founded under the name "Brünner Local Eisenbahn Gesellschaft" (Brno Local Railway Company). The steam traffic did not disappear even after the electrification of passenger traffic. The number of steam locomotives was only reduced to four, which were used in freight siding and could only be included in passenger transport in the event of power outages or to cope with increased traffic on Sundays and holidays [53,54,56].

The last steam locomotive "Caroline" (now an exhibit of the Technical Museum in Brno) delivered railway trucks through the city streets of Brno until February 1926. This ended the first stage of steam traffic on the Brno street traffic tracks. The second stage of steam operation occurred in the 1940s after connecting the local railway Brno-Lišen to the Society of Brno Electric Street Railways [53,54,56].

In 1900, the Austrian company "Österreichische Union Elektrizitäts Gesellschaft" began in Brno with an electrically powered street railway. In 1900, a joint-stock company with the city of Brno "Gesellschaft der Brünner elektrischen Strassenbahnen" (Brno Electric Street Railways Company) was established. This company is the direct predecessor of today's transport company. Its operation started on 21 June 1900, on modified steam lines $[53,54,56]$.

After constructing other lines, at the end of 1903, five lines were in operation, distinguished by colored targets. The fleet consisted of 41 motor and 12 towing cars manufactured in Graz and 29 modified towing cars from horse and steam railway. The first domestic cars were seven motor cars from the Brno company Lederer-Porges (later Královopolská strojírna) delivered from 1903 to 1904. The old depot in Pisárky was rebuilt for electric operation, and a new one was built in Králové Pole (now it serves as a substation building). Before the First World War, the street railway network underwent only partial modifications and changed $[53,54,56]$.

The 1920s and 1930s were marked by the rapid development of the railway and the related changes. The expansion of tram lines and facilities for buses were built in Husovice and two new substations with fully automated operation, i.e., Tábor (1926) and Křrižová $(1928)[53,54,56]$.

Between 1930 and 1945, Brno Street Railways Company introduced bus transport to supplement the existing tram transport. By the end of 1938, 11 bus lines were in operation. The Second World War had a very negative effect on the entire urban transport system. After the bombing of Brno, a significant part of vehicles and equipment was destroyed. The renewal of tram traffic took numerous months. In addition to repairs to damaged tram lines, it was also necessary to ensure the revival of the overhead line, which was up to $60 \%$ devastated. The electric operation was not fully resumed until 1945 on ten lines with a total length of $74.6 \mathrm{~km}$. After the war, bus transport had to be rebuilt from scratch, as most of the operational buses were confiscated by the retreating Nazi army $[53,54,56]$.

In 1951 to 1970, The original joint-stock company operating public transport had been replaced at the end of the 1940s by a municipal company, which from 1951 was given the current name Dopravní podnik města Brna (DPMB) [39,53]. By the 1960s, there was no significant expansion of rail transport, which was completed in the post-war years. A significant modernization of the tram fleet began with introducing four-axle T-series trams from ČKD Prague, derived under the license of American PCC cars. In 1967, the fleet was supplemented by $\mathrm{K}$ articulated vehicles [53,54,56].

In 1968, the company operated 17 permanent lines with a total length of $158 \mathrm{~km}$. The operation of more powerful traction vehicles has significantly increased the demands on the traction power supply system. In 1970, 10 stable substations with a total output of $30 \mathrm{MW}$ were in operation. Bus transport has become a seemingly simple solution for transport services in new housing estates. However, the fuel crisis in the 1970s again turned its attention to electric traction. The city of Brno, as one of the few cities in the Czech Republic that did not succumb to the tendency to disrupt the lines, could proceed to the renaissance of trolleybus traffic. Several new tram lines were built along separate bodies to 
serve new satellite housing estates. However, these high-capacity sections were connected to the existing rail system in the city center $[53,54,56]$.

In the 1980s and 1990s, the operational stagnation of the system began to show. The rapid growth of individual motoring had exposed public transport to a sharp confrontation. Therefore, the city management adopted a decision on the organizational change of the public transport system as a measure with temporary effect until the final solution to the rail system's capacity. The new system was implemented in 1995. The change in the organization of public transport operation was caused by the need to streamline its operation. Emphasis was placed on the preparation and implementation and maximum use of tram and trolleybus traction and reduction in parallel bus lines (Table 1). The ecological situation of the city center and other vital localities were considered to modify the tram network $[53,54,56]$.

Table 1. Number of transport lines in Brno city based on DPMB data - prepared by authors $[53,55,56]$.

\begin{tabular}{cc}
\hline Transport Lines & Number \\
\hline Tram lines (of which depart from the city of Brno) & 11 \\
Trolleybus lines (of which depart from the city of Brno) & 13 \\
City bus lines daily (of which depart outside the city of Brno) & 43 \\
City night bus lines (of which depart outside Brno) & 11 \\
Regional bus lines running on the territory of the city of Brno & 29 \\
\hline
\end{tabular}

\section{Results and Discussion}

\subsection{Governance of Brno City}

Brno city has been found to be one of the cities outstanding smart city governance in the Czech Republic and Europe, and the globe. Brno city governance is considered to have the willingness to improve the livelihood of the city dwellers and the environmental aspects of the city's development. Amongst Czech cities, Brno city showed strategic planning, strength and willingness $[58,59]$. The city with a long history of planning for building and transport development dates back to the 18th century. It has numerous plans for the city ranging from waste management, energy, transport, environment, water, education, health care, and safety [51-54,58].

Brno has now projected their long-term vision, i.e., Vision2050 [51]. It also has shortterm development goals that subscribe to Vision2050 [51,52]. Even though Brno city has some of the best planning documents for achieving smart city sustainability, Brno struggled with decision making regarding implementing the planning documentations and vision [57]. This is where the role of governance comes in. Governance and management provide the day-to-day administration and implementation of the plans and vision of the cities. However, this faces many challenges from the political changes in the towns as each political party comes with its agenda and objectives [51]. Brno city scored highly in aspects of administration and experts regarding implementation of the city plans, but it was suggested that it still suffers the political changes whose terms change with time [44,51].

\subsection{Transport in Brno City}

Brno was found to have an integrated and intelligent transport system [22,53-56]. We noted that Brno had come a long way in systematically planning and improving its transport system (Table 1, and Figures 3 and 4). On the ground, we observed that the transport system in Brno is not just the trams and bus lines and the infrastructures, but also the connection with technology, connections with energy, water and waste management of the city. To achieve smart city sustainability, cities have to take a multidimensional approach to implement the aspects of development aiming to achieve a good quality of life for the people in the city [22,59]. This is the conceptualization of this study, which we referred to as an integrated approach. 


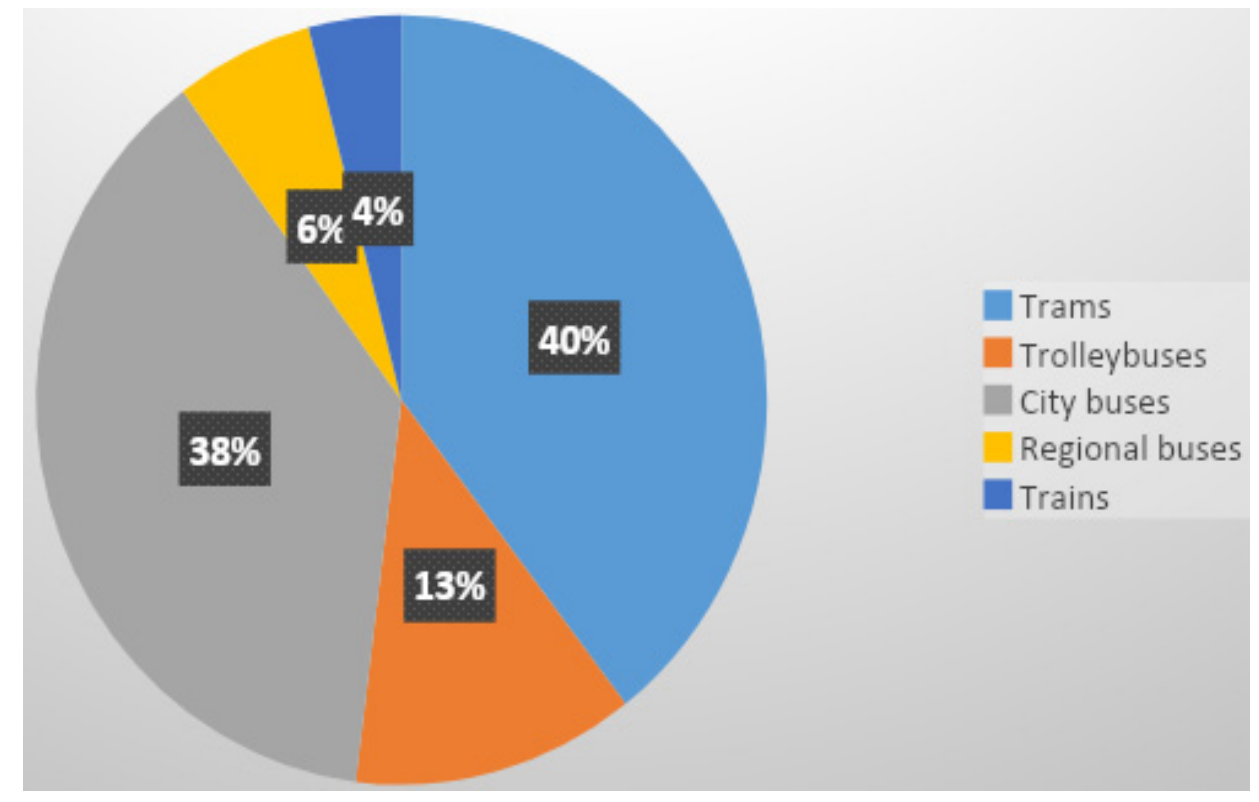

Figure 3. Brno share of public transport vehicles by the end of 2019 based on DPMB data-prepared by authors $[43,54,55]$.

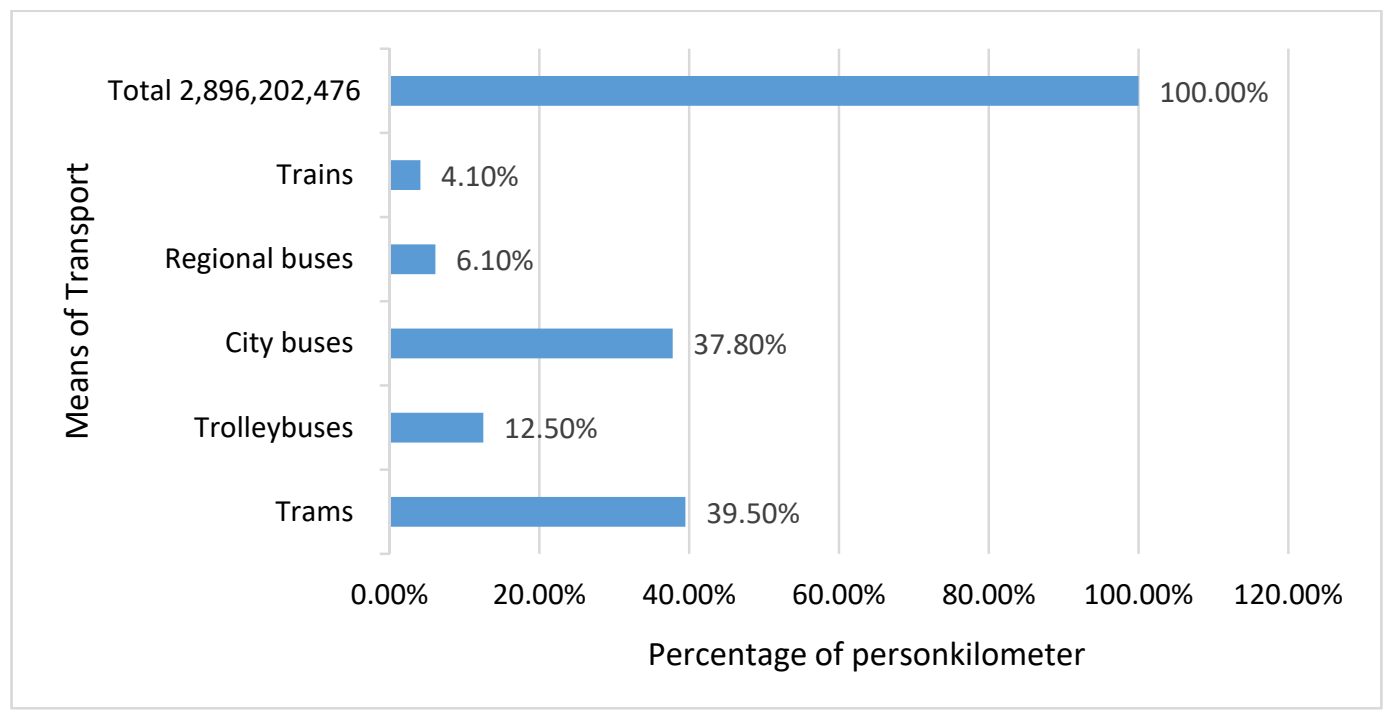

Figure 4. Passengers distribution in Brno District in 2019 (personkilometer) - prepared by authors [55].

The Brno transport system is interconnected with numerous connections. These connect buses to trams and vice versa. This is supplemented by the regional trains and buses, which bring people outside the city of Brno city, hence connecting to their destination in and around the city (Figures 3 and 4) [22,53-57].

The Brno transport system is complementary to the economic development of the city. The movement of people and goods in the city is seen to be very well connected as well. The city transport alone made profits accounting for the year 2019 was reported at the amount of CZK 98,437,625.71 [53-56,58,59]. The company's (DPMB-Dopravní podnik města Brna, a.s.) [55,56] own management in 2019 had a positive performance both in the public service obligation and in business/commercial activities. In 2019, DPMB reached its largest year-on-year increase in the cost of repairs, especially infrastructure, at CZK $358,292,930[55,56]$.

The total revenues in 2019 were CZK 3,324,316,437.81 with a year-on-year increase in CZK 89,359,107.22. Only revenues from profitable commercial transport improved by CZK 
$90,552,953.36$ continuously from previous years. This development had a key impact on the economic result and activities in the transport sector $[55,56]$.

Lately, DPMB, the Brno city transport company, has heavily invested in transport and technology investments. This involves the other interconnections of water, waste management as well as energy. The company invested in new trams, buses, and the internet, among other technologies such as a central public transport control center for the whole city (Figures 3-6).

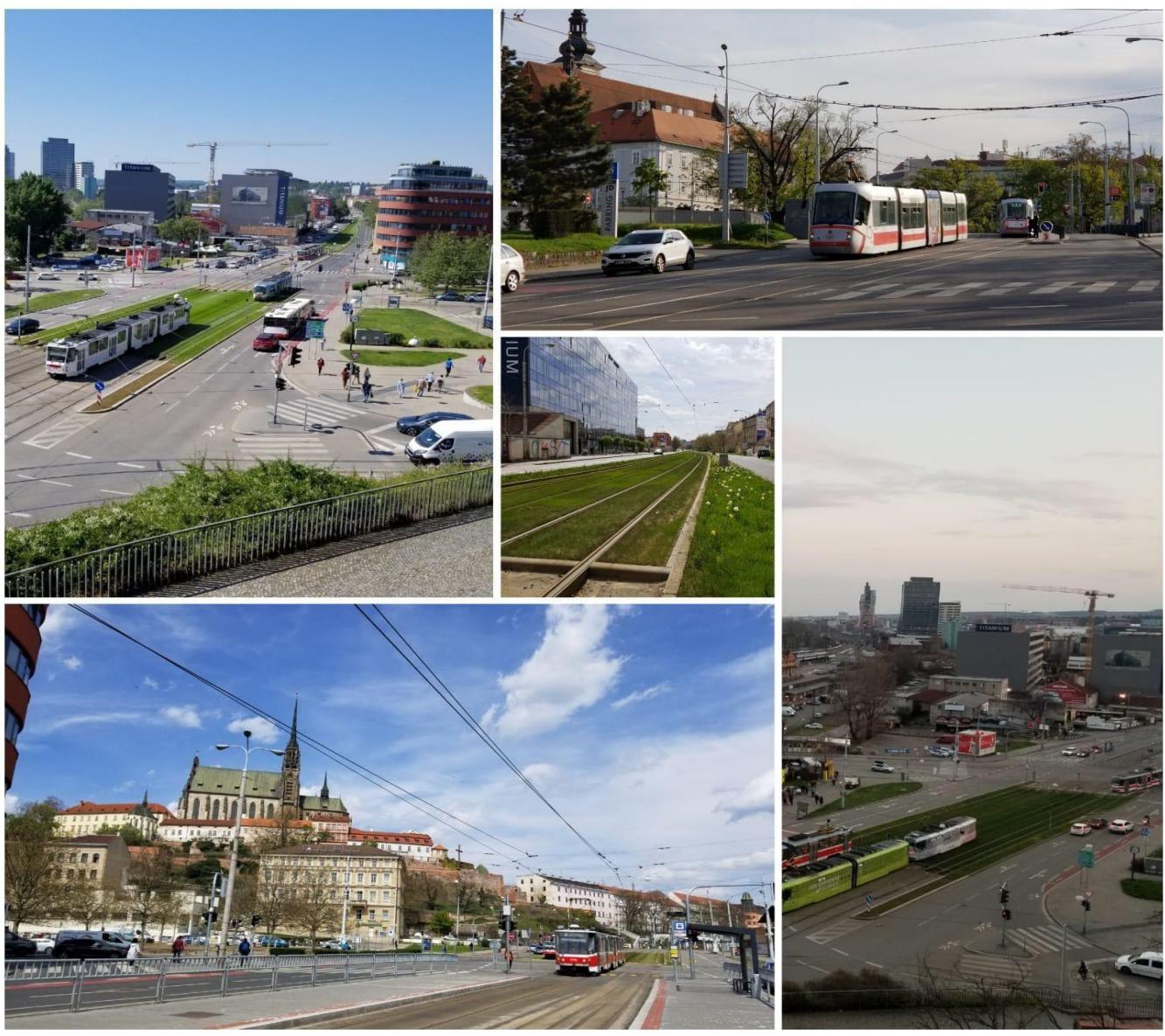

Figure 5. Brno city Tramlines, trams, and greenery on the tram lines (Photos: Dastan Bamwesigye).

The Brno city transport company has also improved payment conditions from cash to pay by cards facilitated by the internet. The station ticket machines are still in operation for those who want to buy by cash on most tram or bus stations.

All public transport offers free internet and apps such as "IDOS" where passengers can quickly search for their connections and stops. This makes the livelihood for city dwellers in Brno not only easy but also efficient.

Based on the Smart City and Sustainability Model (SCS Model), the Brno city transport system is connected to other components of smart city such as energy, ICT, and environment (Figures 5 and 6). Nonetheless, a few things such as strictly only bus and trolley bus lines could reduce traffic during rush hours. Moreover, they would motivate more working class to use public transport if no delays. This has been implemented in some cities in the world, especially in the Netherlands [22]. Cycling structures in the old infrastructure had not been catered for, scaring away many potential daily cycling to work and leisure. As mentioned, new structures seem to care for cycling and pedestrians but still on a small scale. 

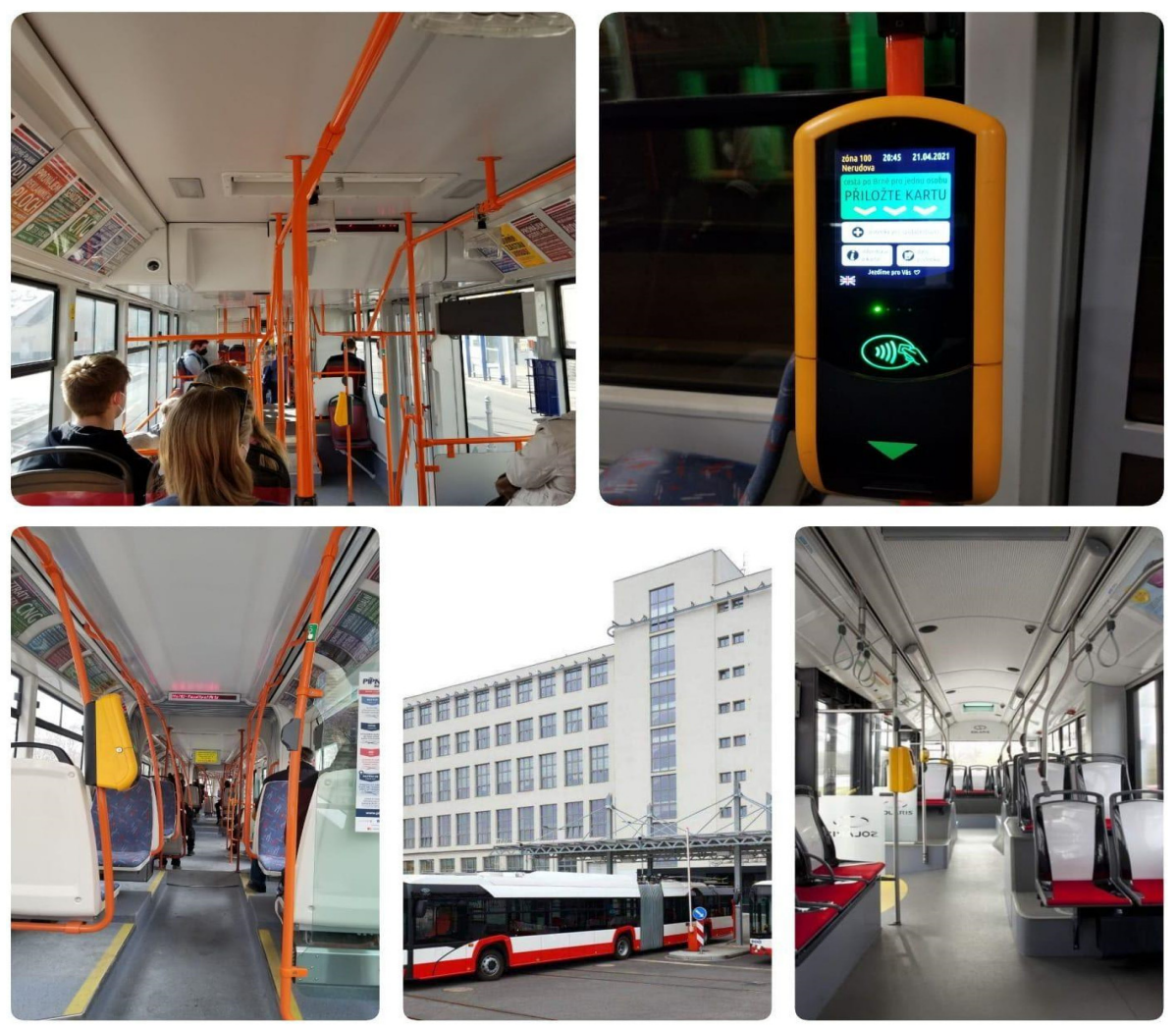

Figure 6. Trams and Buses, and internet payment options (Photos: Dastan Bamwesigye).

\subsection{Integration between Transport, Building, and Green Spaces in the City}

The management and administration of the city of Brno have demonstrated a balance between the built areas, green spaces and playfields, and buildings. This is shown in the plans and can also be seen physically on the earth maps and by observation. We observed that according to the prerequisites of smart and sustainable cities, Brno has done very well even if it still has a lot to do to keep the balance [22,41,42,58-61].

We observed that much of the green zones are in the peripheries of Brno. However, there are many green zones in Brno. Some of these are playfields while others are arboretum gardens with various vegetations (Figures 5 and 7) [41-43,57-61]. These serve as leisure spaces for the city dwellers and tourists since some of them are conserved by international declarations.

The greenery systems and urban nature ecosystems help reduce urban pollution by reducing the carbon dioxide $(\mathrm{CO} 2)$ in the atmosphere. In the same process, greeneries also provide clean air for the urban population and animals [22,51,52]. Therefore, the ecological and environmental development roles of integrating greenery systems in the transport, and built areas is of paramount functions $[22,26,58,59,62-73]$. We can ably argue that the urban dwellers also enjoy psychological benefits from interacting with urban nature [74-76]. By merely looking at nature, it is very relaxing for the brain and body for some people.

Smart cities are gradually becoming our reality. It can be seen, for example, based on scientific publications on this subject, the number of which increased 120 times in 20 years from 138 in 1996 to 16,500 in 2015 [7]. However, in the opinion of some scientists [4], the effects of implementing the smart city policy are not sufficiently taken into account in scientific research. Nevertheless, an analysis of the literature on the subject by Bhosale et al. [7] indicates that the scope of research on S.C. goes beyond the technological aspect itself, especially concerning Europe. The subject matter of these scientific works considers a more holistic interpretation of smart cities, emphasizing that their development depends on the balance between human, economic, social, cultural, environmental, and technological factors [22,44,61-64,78-83]. 

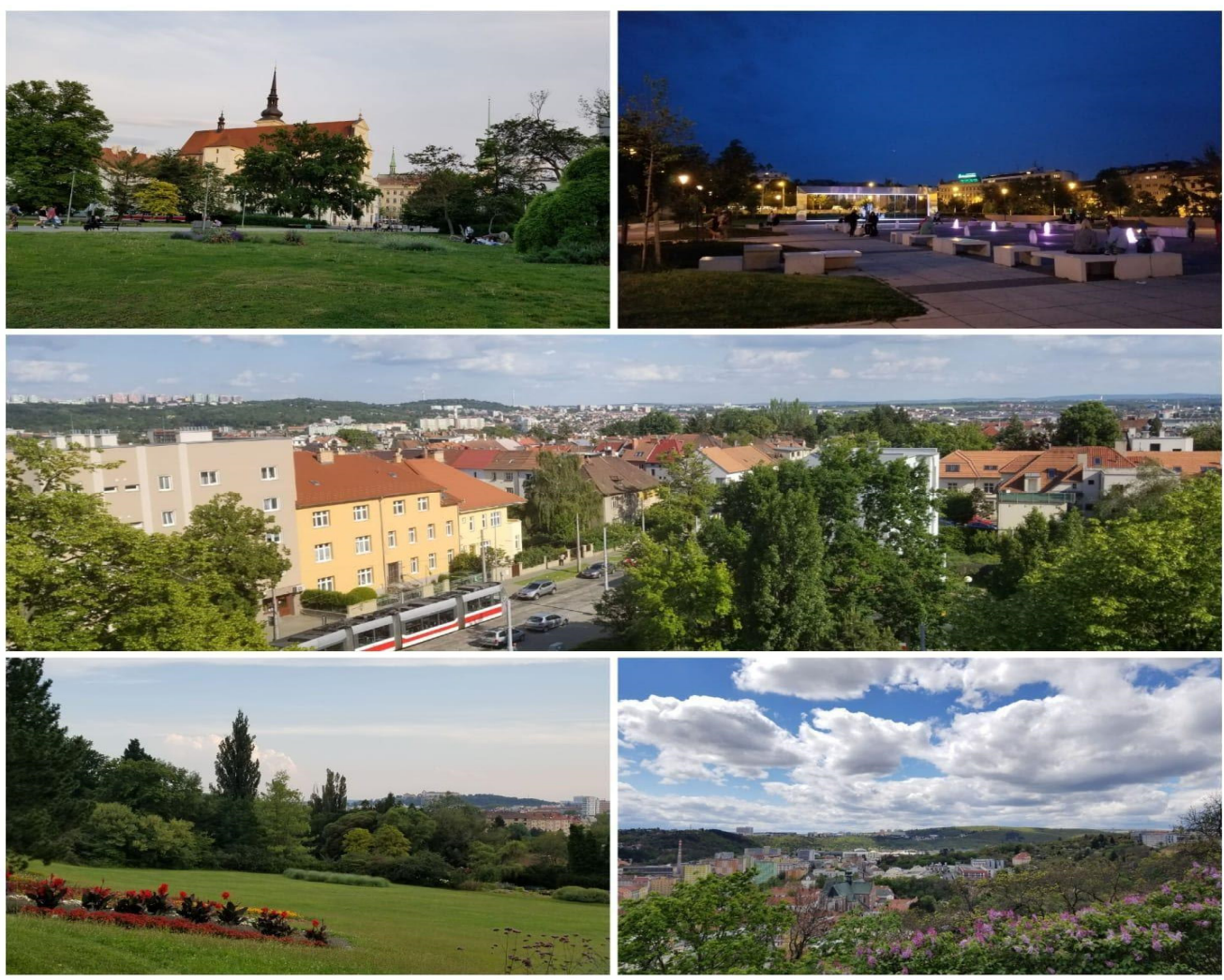

Figure 7. Open spaces and green zones, building and transport integration in Brno (Photos: Das$\tan$ Bamwesigye).

Since the term "smart cities" is, in a sense, still a new term, its meaning can be misleading. The colloquial meaning of S.C. is understood as using the data (continuously increasing) gathered thanks to ICT to guide the decision-making process in the city. However, a more critical look at the "smart city" may suggest a clever marketing concept designed to promote the industry of the largest ICT companies with a vested interest in selling their products and processing citizens' data for commercial purposes. In this context, there are concerns, such as privacy breaches resulting from the introduction of hidden electronic surveillance systems increasingly used in the public space $[4,22,77]$.

Regarding the issue of smart cities lately, Hambleton $[4,10]$ notes that cities around the world are now facing four main challenges simultaneously:

- The COVID-19 health crisis;

- A sharp economic slowdown due to the pandemic;

- Growing climate problems;

- An unacceptable increase in social, economic and racial inequalities.

Of course, concerning the above problems, advances in ICT can significantly improve the quality of city management. However, as Hambleton $[4,10]$ states simply obtaining gigantic amounts of data about society (zeta- and yotabytes) will not improve the quality of life in cities. To successfully meet the above challenges, traditional thinking about smart cities should instead be replaced by implementing so-called "wise cities". More so, ICT is an engine of development through use of big data, communication, city operational governance systems and city services becoming highly responsive and quality life [84-86]. Moreover, it is argued that the goal of smart cities is to achieve good quality of life of the people and sustainability of their neighborhoods. This is the ultimate goal of urban utilities in long run $[22,44,78-86]$.

Even though most studies emphasize smart technology [22,44,78-86], Bamwesigye and Hlavackova [22] and Yigitcanlar et al. [78] put emphasis on smart people and their welfare as well as the environmental sustainability. Yigitcanlar et al. [78] concluded that 
smart cities conceptualizations should be linked to achieve desired sustainable practices for efficient improvement of all aspects of smart city.

\section{Conclusions}

This study aimed to explore the case study of Brno city based on the smart city and sustainability model (SCS Model). We analyzed Brno in terms of smart and sustainable city elements, i.e., smart mobility / public transport, smart technology, smart people, smart governance, smart economy, smart living, and smart environment (waste management, public spaces, and greenery spaces/parks) [1,5-14,50-64]. Therefore, we investigated a case study of Brno city in the Czech Republic based on the smart city and sustainable development models mentioned. To explore and analyze major concepts of smart city in the city of Brno.

The literature section dealt with the expounding on smart cities and an in-depth analysis of each element of the smart city. Moreover, the section also studied and explained the means of achieving smart and sustainable cities, such as public service administration and management. We went on to discuss the role played by governance in achieving smart cities. This is because there must be a team of experts implementing this.

We used qualitative techniques such as case study, exploration, and description. We were able to analyze and comprehend the trends in the diverse features of the smart city and sustainable development of the city of Brno.

The findings showed that Brno city is doing its best to maintain smart city models already built through its governance organs and structures. The city is also working hard to improve some of the aspects that are still lagging. For example, new streets have bigger walking pavements with riding lanes. The ongoing developments and the future ones are based on strategic planning, which considers both the short term and long term such as Brno2023, Brno2030, and Brno2050, as well as the needs of the people.

It was found that Brno has a very well-planned transport system and is linked with other aspects such as technology (internet and other technologies such as payment systems), energy, such as the electricity that moves the trolleybuses and trams, solar innovations, and environment. The system of Brno city is very interconnected in terms of transport, energy, and environment, referred to in this study as the smart city and sustainability model. These three aspects are also linked with the building systems and built areas. We strongly conclude that even though Brno city still struggles to achieve total sustainability, it is still a model and reflection of a smart and sustainable city. From infrastructure development, technology, and the green spaces and nature in and around the city, one would appreciate the efforts to balance infrastructure development, technology, and nature to benefit the people and environment [61-64,78-83]. Such an integrated approach and conceptualization could inform policy making and practice that can achieve smart city and sustainability [78-81].

We observed a few deficits, which are not limited to:

There are limited cycling lanes in the city. However, much the city and development partners have bought and distributed cycles and scooters in and around the city, the number of safe demarcated lines is still limited. This could be linked to structural designs, which previously did not cater for such.

Other small aspects have not been carefully catered to the challenges of space in the city and the increasing city population. Given the space between parked cars and the buildings, it is very hard for pedestrians and disabled people in wheelchairs to use in some streets.

Lastly, we noted that Brno city has very good plans and vision with other studies [11-13,22,44-60,78,79]. This has been referred to as the "DNA" of smart cities [78-80]. However, the implementation still suffers political changes. This is attributed to the term of office change and each political party having different ideas that sometimes shadow the city's overall objective of sustainable development [44]. 
Author Contributions: Conceptualization, D.B.; methodology, D.B.; validation, J.F., J.Ł. and B.F.-A.; formal analysis, D.B.; investigation, D.B.; resources, J.F.; data curation, D.B.; writing-original draft preparation, D.B. and J.F.; writing-review and editing, J.Ł. and B.F.-A.; visualization, D.B.; supervision, J.Ł. All authors have read and agreed to the published version of the manuscript.

Funding: This research received no external funding.

Institutional Review Board Statement: Not applicable.

Informed Consent Statement: Not applicable.

Conflicts of Interest: The authors declare no conflict of interest.

\section{References}

1. Raynal, M. Distributed Algorithms and Protocols; Wiley: Chichester, UK, 1988.

2. Wemmerlöv, U. A Taxonomy for Service Processes and its Implications for System Design. Int. J. Serv. Ind. Manag. 1990, 1, 20-40. [CrossRef]

3. Hall, R.E. Intertemporal substitution in consumption. J. Political Econ. 1988, 96, 339-357. [CrossRef]

4. Hambleton, R. From smart cities to wise cities. IET Smart Cities 2021, 3, 53-55. [CrossRef]

5. Cleeveley, D. Why are smart cities proving to be so hard to deliver? IET Smart Cities 2020, 2, 165-166. [CrossRef]

6. Mossberger, K.; Tolbert, C.J.; McNeal, R.S. Digital Citizenship: The Internet, Society and Participation; The MIT Press: Cambridge, UK, 2008.

7. Bhosale, V.; Raverkar, D.; Lingayat, G. Need of smart city. Contemp. Res. India 2021, 234-239. Available online: https: / / www.researchgate.net/publication/352477932_Need_of_Smart_City (accessed on 1 July 2021 ).

8. Lee, J.H.; Hancock, M.G. Towards an effective framework for building smart cities: Lessons from Seoul and San Francisco. Technol. Forecast. Soc. Chang. 2014, 89, 80-99. [CrossRef]

9. Manville, C.; Cochrane, G.; Cave, J.; Millard, J.; Pederson, J.K.; Thaarup, R.K.; Liebe, A.; Wissner, M.; Massink, R.A.; Kotterink, B. MAPPING SMART CITIES IN THE EU (2014); Report number IP/A/ITRE/ST/2013-02 PE 507.480 European Parliament; Directorate General for Internal Policies, Policy Department Economic and Scientific Policy A: Brussel, Belgium, 2014.

10. Hambleton, R. Cities and Communities beyond COVID-19. How Local Leadership Can Change Our Future for the Better; Bristol University Press: Bristol, UK, 2020.

11. European Commission. Smart Cities. N.D. Available online: https:/ /ec.europa.eu/info/eu-regional-and-urban-development/ topics / cities-and-urban-development/city-initiatives/smart-cities_en (accessed on 15 April 2021).

12. Ristvej, J.; Lacinák, M.; Ondrejka, R. On Smart City and Safe City Concepts. Mob. Netw. Appl. 2020, 25, 836-845. [CrossRef]

13. OECD. Smart Cities and Inclusive Growth: Building on the Outcomes of the 1st OECD Roundtable on Smart Cities and Inclusive Growth. 2020. Available online: http://www.oecd.org/cfe/cities/OECD_Policy_Paper_Smart_Cities_and_Inclusive_Growth.pdf (accessed on 15 April 2021).

14. Peponi, A.; Morgado, P. Smart and regenerative urban growth: A literature network analysis. Int. J. Environ. Res. Public Health 2020, 17, 2463. [CrossRef]

15. Gil-Garcia, J.R.; Pardo, T.A.; Nam, T. What makes a city smart? Identifying core components and proposing an integrative and comprehensive conceptualization. Inf. Polity 2015, 20, 61-87. [CrossRef]

16. Gonzalez, E.L.; Chinelli, C.K.; Azevedo Guedes, A.L.; Vazquez, E.G.; Hammad, A.W.; Haddad, A.N.; Pereira Soares, C.A. Smart and Sustainable Cities: The Main Guidelines of City Statute for Increasing the Intelligence of Brazilian Cities. Sustainability 2020, 12, 1025.

17. Sánchez-Corcuera, R.; Nuñez-Marcos, A.; Sesma-Solance, J.; Bilbao-Jayo, A.; Mulero, R.; Zulaika, U.; Azkune, G.; Almeida, A. Smart cities survey: Technologies, application domains and challenges for the cities of the future. Int. J. Distrib. Sens. Netw. 2019, 15, 1550147719853984. [CrossRef]

18. Min, K.; Yoon, M.; Furuya, K. A comparison of a smart City's trends in urban planning before and after 2016 through keyword network analysis. Sustainability 2019, 11, 3155. [CrossRef]

19. Bolívar, M.P.R. Creative citizenship: The new wave for collaborative environments in smart cities. Academia 2018, 31, $277-302$. [CrossRef]

20. Gil, M.T.N.; Carvalho, L.; Paiva, I. Determining factors in becoming a sustainable smart city: An empirical study in Europe. Econ. Sociol. 2020, 13, 24-39. [CrossRef]

21. Paulin, A. Informating smart cities governance? Let us first understand the atoms! J. Knowl. Econ. 2016, 7, 329-343. [CrossRef]

22. Bamwesigye, D.; Hlavackova, P. Analysis of sustainable transport for smart cities. Sustainability 2019, 11, 2140. [CrossRef]

23. Paskaleva, K.; Evans, J.; Martin, C.; Linjordet, T.; Yang, D.; Karvonen, A. Data governance in the sustainable smart city. Informatics 2017, 4, 41. [CrossRef]

24. Voordijk, H.; Dorrestijn, S. Smart city technologies and figures of technical mediation. J. Urban Res. Pract. 2019, 14, 1-26. [CrossRef]

25. Borowski, J.; Fortuna-Antoszkiewicz, B.; Łukaszkiewicz, J.; Rosłon-Szeryńska, E. Conditions for the effective development and protection of the resources of urban green infrastructure. E3S Web Conf. 2018, 45, 1-8. [CrossRef] 
26. Łukaszkiewicz, J.; Fortuna-Antoszkiewicz, B.; Oleszczuk, Ł.; Fialová, J. The Potential of Tram Networks in the Revitalization of the Warsaw Landscape. Land 2021, 10, 375. [CrossRef]

27. Lockwood, F. Bristol's smart city agenda: Vision, strategy, challenges and implementation. IET Smart Cities 2020, 2, 208-214. [CrossRef]

28. Knight Frank Report 2018. Warsaw—Towards a Smart City. Available online: https://content.knightfrank.com/research/1500 /documents/en/warsaw-towards-smart-city-april-2018-5462.pdf (accessed on 15 April 2021).

29. Marsal-llacuna, M. City indicators on social sustainability as standardization technologies for smarter (citizen-centered) governance of cities. Soc. Indic. Res. 2016, 128, 1193-1216. [CrossRef]

30. Faraji, S.J.; Marjan, J.N.; Arash, M. The analysis of smart governance scenarios of the urban culture in multicultural cities based on two concepts of "cultural intelligence" and "smart governance". GeoJournal 2019, 86, 1-21. [CrossRef]

31. Broccardo, L.; Culasso, F.; Mauro, S.G. Smart city governance: Exploring the institutional work of multiple actors towards collaboration. Int. J. Public Sect. Manag. 2019, 32, 367-387. [CrossRef]

32. Sanchez-Teba, E.M.; Bermudez-Gonzalez, G.J. Are-smart city projects citizen-centered? Soc. Sci. 2019, 8, 309. [CrossRef]

33. Freudendal-Pedersen, M.; Kesselring, S.; Servou, E. What is smart for the future city? Mobilities and automation. Sustainability 2019, 11, 221. [CrossRef]

34. Buttazzoni, A.; Veenhof, M.; \& Minaker, L. Smart city and high-tech urban interventions targeting human health: An equityfocused systematic review. Int. J. Environ. Res. Public Health 2020, 17, 2325. [CrossRef]

35. Puron-Cid, G. Smart cities, smart governments and smart citizens: A brief introduction. Int. J. E-Plan. Res. 2015, 4, 4-7.

36. Al-Thani, S.K.; Skelhorn, C.P.; Amato, A.; Koc, M.; Al-Ghamdi, S.G. Smart technology impact on neighborhood form for a sustainable Doha. Sustainability 2018, 10, 4764. [CrossRef]

37. Hollands, R.G. Critical interventions into the corporate smart city. Camb. J. Reg. Econ. Soc. 2015, 8, 61-77. [CrossRef]

38. Mutiara, D.; Yuniarti, S.; Pratama, B. Smart governance for smart city. IOP Conf. Ser. Earth Environ. Sci. 2018, 126, 012073. [CrossRef]

39. Meijer, A.; Bolívar, M.P.R. Governing the smart City: A review of the literature on smart urban governance. Int. Rev. Adm. Sci. 2016, 82, 392-408. [CrossRef]

40. Tomor, Z.; Meijer, A.; Michels, A.; Geertman, S. Smart governance for sustainable cities: Findings from a systematic literature review. J. Urban Technol. 2019, 26, 3-27. [CrossRef]

41. Oliveira, T.A.; Oliver, M.; Ramalhinho, H. Challenges for connecting citizens and smart cities: ICT, E-governance and blockchain. Sustainability 2010, 12, 2926. [CrossRef]

42. Gohari, S.; Ahlers, D.; Nielsen, B.F.; Junker, E. The governance approach of smart city initiatives. Evidence from Trondheim, Bergen, and Bodø. Infrastructures 2020, 5, 31. [CrossRef]

43. Tan, S.Y.; Taeihagh, A. Smart city governance in developing countries: A systematic literature review. Sustainability 2020, 12, 899. [CrossRef]

44. Castelnovo, W.; Misuraca, G.; Savoldelli, A. Smart cities governance: The need for a holistic approach to assessing urban participatory policy making. Soc. Sci. Comput. Rev. 2015, 34, 1-16. [CrossRef]

45. Pereira, G.V.; Parycek, P.; Falco, E.; Kleinhans, R. Smart governance in the context of smart cities: A literature review. Inf. Polity 2018, 23, 1-20. [CrossRef]

46. Akande, A.; Cabral, P.; Gomes, P.; Casteleyn, S. The Lisbon ranking for smart sustainable cities in Europe. Sustain. Cities Soc. 2019, 44, 475-487. [CrossRef]

47. Bibri, S.E.; Krogstie, J. The emerging data-driven Smart City and its innovative applied solutions for sustainability: The cases of London and Barcelona. Energy Inf. 2020, 3, 1-42. [CrossRef]

48. Creswell, J.W. Research Design: Qualitative, Quantitative, and Mixed Methods Approaches, 3rd ed.; Sage: Thousand Oaks, CA, USA, 2009.

49. Creswell, J.W. Educational Research: Planning, Conducting and Evaluating Quantitative and Qualitative Research, 4th ed.; Pearson Education: Upper Saddle River, NJ, USA, 2011.

50. Nachmias, D.; Nachmias, C. Content analysis. In Research Methods in the Social Sciences; Edward Arnold: London, UK, 1976; pp. 132-139.

51. Brno2050. Available online: https://brno2050.cz/ (accessed on 15 April 2021).

52. Portal of Spatial Planning of the City of Brno. Available online: https://upmb.brno.cz/ (accessed on 15 April 2021).

53. Dopravní Podnik Města Brna, a.s.-Novinky. Available online: https:/ / www.dpmb.cz (accessed on 15 April 2021 ).

54. Dopravní Podnik Města Brna, a.s.-Firma-Historie. Available online: https:/ / www.dpmb.cz/cs/firma-historie (accessed on 15 April 2021).

55. Rocenka-Dopravy-Brno-2019-pdf-190. Available online: https://www.bkom.cz/informacni-centrum/rocenky-dopravy-brno15/rocenka-dopravy-brno-2019-pdf-190 (accessed on 15 April 2021).

56. DPMB. Available online: https://dpmb.cz/cs / firma-vyrocni-zpravy (accessed on 15 April 2021).

57. Brno Traffic Network Diagrams. Available online: https://dpmb.cz/en/schemata-site-mhd (accessed on 15 April 2021).

58. Janurova, M.; Chaloupkova, M.; Kunc, J. Smart city strategy and its implementation barriers. Theor. Empir. Res. Urban Manag. 2020, 15, 5-21.

59. Nam, T.; Pardo, T.A. Conceptualizing smart city with dimensions of technology, people, and institutions. In Proceedings of the 12th Annual International Digital Government Research Conference: Digital Government Innovation in Challenging Times, New York, NY, USA, 12-15 June 2011; pp. 282-291.

60. Urban Concept Design-Urban and Lanscape (1:25,000). Available online: https://gis.brno.cz/mapa/upmb/?c=-591117.15\%3A$1159865.1 \& z=3 \& l b=z m-b r n o \& l y=u p 2 \& l b o=1 \& l y o=($ accessed on 15 April 2021).

61. Boulevard Visualization. Available online: https://kambrno.cz/aktuality/siroky-bulvar-byty-az-pro-patnact-tisic-lidi-zelenevnitrobloky-i-strechy-priprava-nove-ctvrti-trnita-pokracuje/ (accessed on 15 April 2021). 
62. Cugurullo, F. Exposing smart cities and eco-cities: Frankenstein urbanism and the sustainability challenges of the experimental city. Environ. Plan. A Econ. Space 2018, 50, 73-92. [CrossRef]

63. Brno na Mapě, VisitBrno.cz. Available online: https://www.visitbrno.cz/cz/brno-na-mape/73/?fbclid=IwAR2nC-Oll-73-3q0 tbxvSXFYZG01CwTtPT158-ovHwx9BuxBAugbf4_avzk (accessed on 18 August 2021).

64. Lim, C.; Kim, K.J.; Maglio, P.P. Smart cities with big data: Reference models, challenges, and considerations. Cities 2018, 82, 86-99. [CrossRef]

65. Trindade, E.P.; Hinnig, M.P.F.; Moreira da Costa, E.; Marques, J.S.; Bastos, R.C.; Yigitcanlar, T. Sustainable development of smart cities: A systematic review of the literature. J. Open Innov. Technol. Mark. Complex. 2017, 3, 11. [CrossRef]

66. Allam, Z. Contextualising the smart city for sustainability and inclusivity. New Des. Ideas 2018, 2, $124-127$.

67. Anthopoulos, L.G.; Janssen, M.; Weerakkody, V. Comparing Smart Cities with different modeling approaches. In Proceedings of the 24th International Conference on World Wide Web, Florence, Italy, 18-22 May 2015; pp. 525-528.

68. Komninos, N. The Age of Intelligent Cities: Smart Environments and Innovation-For-All Strategies; Routledge: Oxfordshire, UK, 2014.

69. Gonzalez, R.A.; Ferro, R.E.; Liberona, D. Government and governance in intelligent cities, smart transportation study case in Bogotá Colombia. Ain Shams Eng. J. 2020, 11, 25-34. [CrossRef]

70. Allwinkle, S.; Cruickshank, P. Creating smart-er cities: An overview. J. Urban Technol. 2011, 18, 1-16. [CrossRef]

71. Harrison, C.; Donnelly, I.A. A theory of smart cities. In Proceedings of the 55th Annual Meeting of the ISSS-2011, Hull, UK, 17-22 July 2011.

72. Batty, M.; Axhausen, K.W.; Giannotti, F.; Pozdnoukhov, A.; Bazzani, A.; Wachowicz, M.; Ouzounis, G.; Portugali, Y. Smart cities of the future. Eur. Phys. J. Spec. Top. 2012, 214, 481-518. [CrossRef]

73. Bătăgan, L. Smart cities and sustainability models. Inform. Econ. 2011, 15, 80-87.

74. Wang, X.; Teng, M.; Huang, C.; Zhou, Z.; Chen, X.; Xiang, Y. Canopy density effects on particulate matter attenuation coefficients in street canyons during summer in the Wuhan metropolitan area. Atmos. Environ. 2020, 240, 117739. [CrossRef]

75. Sæbø, A.; Popek, R.; Nawrot, B.; Hanslin, H.M.; Gawrońska, H.; Gawroński, S.W. Plant species differences in particulate matter accumulation on leaf surfaces. Sci. Total Environ. 2012, 427-428, 347-354. [CrossRef]

76. Chee Keng Lee, A.; Jordan, H.C.; Horsley, J. Value of urban green spaces in promoting healthy living and wellbeing: Prospects for planning. Risk Manag. Healthc. Policy 2015, 8, 131-137.

77. Zuboff, S. The Age of Surveillance Capitalism. The Fight for the Future at the New Frontier of Power; Pro le Books Ltd: London, UK, 2019.

78. Yigitcanlar, T.; Han, H.; Kamruzzaman, M.; Ioppolo, G.; Sabatini-Marques, J. The making of smart cities: Are Songdo, Masdar, Amsterdam, San Francisco and Brisbane the best we could build? Land Use Policy 2019, 88, 104187. [CrossRef]

79. Du, M.; Zhang, X.; Mora, L. Strategic planning for smart city development: Assessing spatial inequalities in the basic service provision of metropolitan cities. J. Urban Technol. 2021, 28, 115-134. [CrossRef]

80. Ramirez Lopez, L.J.; Grijalba Castro, A.I. Sustainability and Resilience in Smart City Planning: A Review. Sustainability 2021, 13, 181. [CrossRef]

81. Hollands, R.G. Will the real smart city please stand up? Intelligent, progressive or entrepreneurial? In The Routledge Companion to Smart Cities; Routledge: Oxfordshire, UK, 2020; pp. 179-199.

82. Doli, A.; Bamwesigye, D.; Hlaváčková, P.; Fialová, J.; Kupec, P.; Asamoah, O. Forest Park Visitors Opinions and Willingness to Pay for Sustainable Development of the Germia Forest and Recreational Park. Sustainability 2021, 3, 3160. [CrossRef]

83. Klusacek, P.; Konecny, O.; Zgodova, A.; Navratil, J. Application of the smart city concept in process of urban recycling-Case study of Špitálka in Brno, Czech Republic. Deturope Cent. Eur. J. Reg. Dev. Tour. 2020, 12, 22-40.

84. Evans, J.; Karvonen, A.; Luque-Ayala, A.; Martin, C.; McCormick, K.; Raven, R.; Palgan, Y.V. Smart and sustainable cities? Pipedreams, practicalities and possibilities. Local Environ. 2019, 24, 557-564. [CrossRef]

85. Kitchin, R. The ethics of smart cities and urban science. Philos. Trans. R. Soc. A Math. Phys. Eng. Sci. 2016, $374,20160115$. [CrossRef] [PubMed]

86. March, H. The Smart City and other ICT-led techno-imaginaries: Any room for dialogue with Degrowth? J. Clean. Prod. 2018, 197, 1694-1703. [CrossRef] 